Chimia 45 (1991) 311-316

(c) Schweiz. Chemiker-Verband; ISSN 0009-4293

\title{
The Change in Research for the Therapy of Tumors
}

\author{
H.-Harald Sedlacek*, Dieter Hoffmann, Jörg Czech, Cenek Kolar, Gerhard \\ Seemann, Detlef Güssow, and Klaus Bosslet
}

\section{Introduction}

Cytostatics, hormones, and hormone antagonists are families of drugs with proven activity in a limited number of systemic, i.e. disseminated tumor diseases. The parenteral drug of each family has been detected decades ago. A considerable number of primordial cytostatics were either detected by an accidental specific clinical or preclinical observation [1-3] or on the basis of a broad in vitro and in vivo tumor screening system [4]. The success of both approaches was based on lucky chances. Some cytostatics and the hormones and hormone antagonists were found on a more rational basis. With increasing knowledge in the cellular synthesis of the DNA and in the hormonal dependence of the growth of normal and tumor cells, biological structures (enzymes, hormone receptors) could be identified the blockage of which promised an inhibition of cell proliferation. Once such targets were identified, substrate analogues to block the specific enzymes or of hormone derivatives to block the receptors were designed. When recognizing the therapeutic potency as well as the failure and toxicity of each parenteral drug its structure was modified to find by trial and error derivatives with improved activity. With the recognition of the structure activity relationship the rational design of new and further improved compounds still belonging to each family tree of structures was possible.

This approach took place with cytostatics like alkylating agents, antibiotics like anthracyclines, mitomycins, with toxins inactivating enzymes (i.e. topoisomerase) or intracellular structures (i.e. tubulin), and antimctabolites (folic-acid antagonists and others) [5-14].

The antitumoral activity of hormones (progestins and androgens and derivatives) or antihormones (antiestrogens, antiandro-

\footnotetext{
*Correspondence: PD Dr. H.-H. Sedlacek Research Laboratories of Behringwerke P.O. Box 1140

D-3550 Marburg
}

gens, antiprogestins, aromatase inhibitors, and LH-RH-antagonists) were likewise improved [15-17].

However, in spite of the clinical success of cytostatics, hormones, and antihormones we are far behind our research aims in tumor therapy. Today only 6-7\% of tumors can be cured by cytostatics. In about $40 \%$ of tumors treatment with cytostatics or hormones or hormone antagonists leads to a transient tumor regression and/or to an increase in survival time, which is limited by development of resistance of the tumor against any further treatment.

This development of resistance as well as the insensitivity of more than $50 \%$ of all tumors to any kind of treatment is still the biggest provocation for academic as well as industrial tumor research.

This challenge has been taken with various new approaches:

For instance the screening systems to detect new cytostatic compounds was changed. The change consisted in the use of slowly proliferating human tumors being clinically resistant to any kind of treatment instead of quickly proliferating murine tumors. The rational of this change was that compounds being active on slowly proliferating tumors might not be active on quickly proliferating tumors and thus might have been missed in former screening programs with murine tumors [4]. Indeed new cytostatic antibiotics active in vitro and in vivo on human tumors could be found [18-28] but till now none of these compounds revealed a breakthrough in the treatment of tumor patients while with a part of these compounds new hitherto unknown toxic side effects could be observed.

We were one of the first institutions, which made this experience using a battery of slowly growing human tumors. Very early we started a screening system for natural compounds with antiproliferative activity. We had been successful so far that we detected Rodorubicin (HLB 817) (7-L-rhodosaminyl,2-desoxy-L-fucosyl-L-cinerulosyl)-(10-L-rhodosaminyl)- $\beta$-rhodomycinon. In vitro Rodorubicin (HLB 817) is not active on quickly growing murine tumors, but has antitumoral activity on human tumors especially on colon carcinomas [29]. Clinical studies, however, had to be stopped due to high grade toxicity of Rodorubicin for endothelial cells [30][31]. Due to this experience and facing the risk $v s$. benefit ratio we stopped the whole screening system.

Another new approach in tumor research was the clarification of the various mechanisms the tumor cell develops to become resistant to a tumor therapeutic drug. To these mechanisms belong the increase in intracellular level of glutathion or increase in quantity and function of a $\mathrm{Ca}^{2+}$ ion dependent transmembraneous glycoprotein, which pumps toxic compounds out of the cell. Inhibition of these mechanisms, for instance by $\mathrm{Ca}^{2+}$ antagonists or lipophilic compounds, seems to restore sensitivity to cytostatic drugs of the resistant tumor cell [4].

A further approach arose from the increasing knowledge in the components, functions, and control mechanisms of growth of different normal cell types including those of the immune system. This knowledge helped us to describe and to understand at least in sections the misbehavior of cells, especially of malignant cells, and the correlation and interaction between tumor cells and the immune system. The hypothesis of the immune surveillance of tumor growth restimulated the old research to find immunological ways of treating tumor diseases [32]. Antigen specific as well as nonspecific approaches were tested preclinically as well as clinically.

The results of more than three decades of intensive and broad evaluations of nonspecific immunostimulators are less than moderate. Indeed bovine mycobacteria (BCG) locally applied into the urine bladder reduced recurrence of bladder cancer [33], the immunomodulator levamisole when applied in combination with the antimetabolite 5-FU increased survival in colon carcinoma [34], $\alpha$-Interferon proved to be curative for hairy cell leucemia [35], and $\alpha$-Interferon as well as Interleukin-2 induced tumor regressions in kidney tumors and melanomas [35-36]. A breakthrough in tumor therapy, however, has not been achieved till today.

The same is true for antigen specific approaches irrespective, whether they are tumor cell vaccines or monoclonal antibodies [32][37] directed against tumor associated antigens. This overall frustrating balance led in several industrial institutions to the consequence either to reduce or to stopcancer research.

The strongest motivation to engage ourselves in tumor research was the increasing knowledge in cell physiology, biology, and immunology of tumor cell growth, enabled by the breakthrough in the development of new techniques in human tumor xenotransplantation, in molecular biology resp. genetechnology, monoclonal antibody production, and antibody engineering. This 
investment into tumor research revealed the following main results:

\section{Bifunctional Cytostatics}

The rational was the improvement of the antitumoral activity of a compound by the synthetic combination of two structures with proven antitumoral activity [38], namely an intercalating and an alkylating structure. One of the compounds synthesized, which carries the above mentioned structural and functional characteristics, is $B 880308$ [39] a compound, which demonstrates activity on tumor cells being sensitive or being made resistant to standard cytostatic drugs [40]. On human tumors transplanted into immunodeficient $(\mathrm{nu} / \mathrm{nu})$ mice, $B 880308$ revealed to be at least similar or stronger active than all standard anthracyclines [40]. In all human ovarian carcinomas tested till now $B 880308$ induced either partial or even complete responses and seems at least experimentally to be the most effective cytostatic compound on this tumor type (see Table I) [49]. Bone marrow toxicity seems to be the dose limiting toxicity [40]. In cooperation with the NCI, Bethesda, USA, further preclinical comparative studies are ongoing now to evaluate in more detail the antitumoral activity and toxicity of this compound.

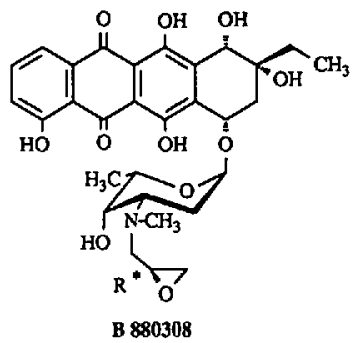

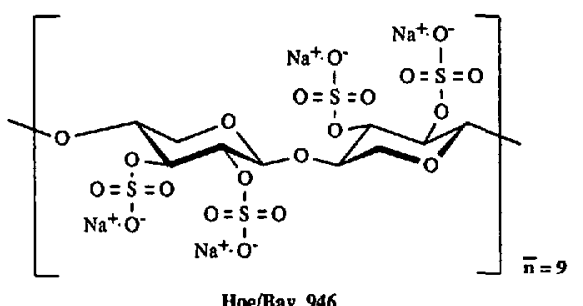

Hoe/Ray 946<smiles>CN1CCC(c2c(O)cc(O)c3c(=O)cc(-c4ccccc4Cl)oc23)CC1</smiles>

\section{Growth Factor Inhibitors}

Quite different to cytostatic research is the project to find inhibitors for growth factors. We started this project about 5 years ago based on the physiological data on cell growth control, on growth factors, and growth

Table 1. Antitumoral Activity of B 880308 [40]

\begin{tabular}{|c|c|c|c|c|c|}
\hline \multicolumn{6}{|l|}{ In vitro } \\
\hline \multirow{2}{*}{\multicolumn{2}{|c|}{ cytotoxicity }} & \multirow{7}{*}{\multicolumn{4}{|c|}{$\begin{array}{l}1 C_{50}=0.001 \mathrm{~g} / \mathrm{ml} \\
10 \times \text { stronger than Doxorubicin } \\
\text { no cross-resistance to } \\
\text { anthracyclines (Doxorubicin) } \\
\text { topoisomerase inhibitors (Etoposide) } \\
\text { spindle toxins (Vinblastin) } \\
\text { DNA reacting compounds (Cisplatin, } \\
\text { Melphalan) }\end{array}$}} \\
\hline & & & & & \\
\hline \multirow{5}{*}{\multicolumn{2}{|c|}{ cross-resistance }} & & & & \\
\hline & & & & & \\
\hline & & & & & \\
\hline & & & & & \\
\hline & & & & & \\
\hline \multicolumn{6}{|l|}{ In vivo } \\
\hline \multicolumn{6}{|l|}{ murine tumors: } \\
\hline \multirow{2}{*}{\multicolumn{2}{|c|}{$\begin{array}{l}\text { leukemia } \\
\text { melanoma, ovarian carcinoma } \\
\text { colon carcinoma }\end{array}$}} & \\
\hline & & & & & activity similar to Doxorubicin \\
\hline & & \multicolumn{4}{|c|}{ Regression of human tumors } \\
\hline \multicolumn{2}{|l|}{ human tumors } & $>80 \%$ & $>50 \%$ & $<50 \%$ & no effect \\
\hline \multicolumn{2}{|c|}{ Transplanted into kidneys of nude mice } & \multicolumn{4}{|c|}{ Number of tumors each from a different patient } \\
\hline \multirow[t]{2}{*}{ bronchial tumors } & $B 880308$ & 1 & 1 & 5 & - \\
\hline & Doxorubicin & 1 & 3 & 2 & - \\
\hline \multirow[t]{2}{*}{ colon tumors } & В 880308 & - & 1 & 3 & - \\
\hline & Doxorubicin & - & 1 & 3 & - \\
\hline \multirow[t]{2}{*}{ ovarian tumors } & В 880308 & 2 & 1 & - & - \\
\hline & Doxorubicin & - & - & 2 & 1 \\
\hline \multicolumn{6}{|c|}{ Transplanted subcutaneously into nude mice } \\
\hline \multirow[t]{2}{*}{ bronchial tumors } & B880308 & 1 & 1 & 1 & - \\
\hline & Doxorubicin & 1 & - & 2 & - \\
\hline \multirow[t]{2}{*}{ colon/GI tumors } & В 880308 & - & - & 2 & - \\
\hline & Doxorubicin & - & - & 2 & - \\
\hline \multirow[t]{2}{*}{ ovarian tumors } & B 880308 & 1 & 4 & - & - \\
\hline & Doxorubicin & - & - & 5 & - \\
\hline
\end{tabular}

factor receptors coded by protooncogenes and oncogenes. Since that time it is known that growth factors like epidermal growth factor (EGF), transforming growth factor $\alpha$ (TGF $\alpha$ ), insulin like growth factor I (IGFI), fibroblast growth factor (FGF), platelet derived growth factor (PDGF), and other factors are mitogens, i.e. they stimulate normal cells as well as tumor cells to proliferate. In part these factors are produced by the tumor cells themselves (autocrine stimulation), in part they are produced by neighboring cells (paracrine stimulation) irrespective, whether they are tumor cells or normal cells.

For being mitogenic the growth factors bind to a specific receptor on the membrane of the target cell. This binding is of a relative high affinity (binding constants in the range of $10^{9}-10^{10} \mathrm{l} / \mathrm{mol}$ ). Binding of the growth factor to its receptor leads to dimerization of neighboring receptors and activation of the tyrosine phosphokinase (TPK), which is the cell internal part of the receptor. The activated TPK activates via phosphorylation of serine kinases, which transfer the activation signal within the intracellular signal transduction. Nearly $70-80 \%$ of all tumors expose a considerable number of growth factor receptors $\left(10^{3}-10^{6}\right.$ per cell) and consequently are influenced in their growth by growth factors.
In addition some tumors have truncated or mutated growth factor receptors. Such truncated receptors may lack the cell external part responsible for binding of the growth factor. They possess, however, the cell internal part, which is constitutively activated. This constituted activation leads to a persistent growth stimulation, which can not be regulated by different concentrations of growth factors because the cell external part of the receptor is lacking [41].

The aim of our research was to find compounds able to inhibit TPK. At the beginning of this work it was completely unclear, whether TPK of different sources are different to such a degree that inhibitors can be found, which inhibit with preference growth of tumors [4]. Consequently, we screened for inhibitors with the use of the TPK of the EGF receptor prepared from tumor cells [42]. According to our hopes we found two different compounds, which inhibit the EGF receptor-associated TPK, block the cell growth stimulating activity of growth factors like EGF and bFGF, and suppress tumor proliferation in vitro and in vivo. To our surprise both inhibitors seem not to effect at tumor therapeutic dosages the TPK of other origin as for instance the TPK of the insulin receptor. 
Table 2. Enzyme Inhibition and Antiproliferative Activity of Hoe/Bay 946 [43a]

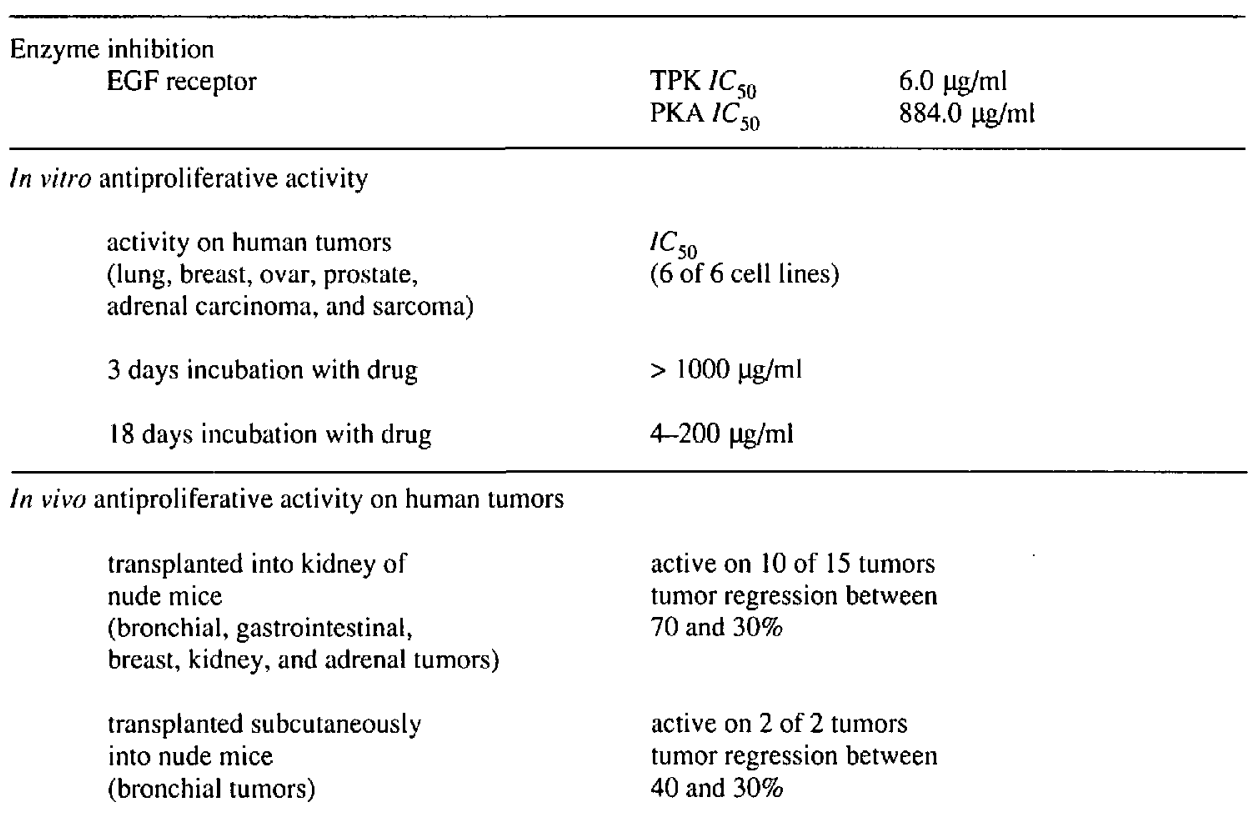

Table 3. Enzyme Inhibition and Antiproliferative Activity of L 868275 143b]

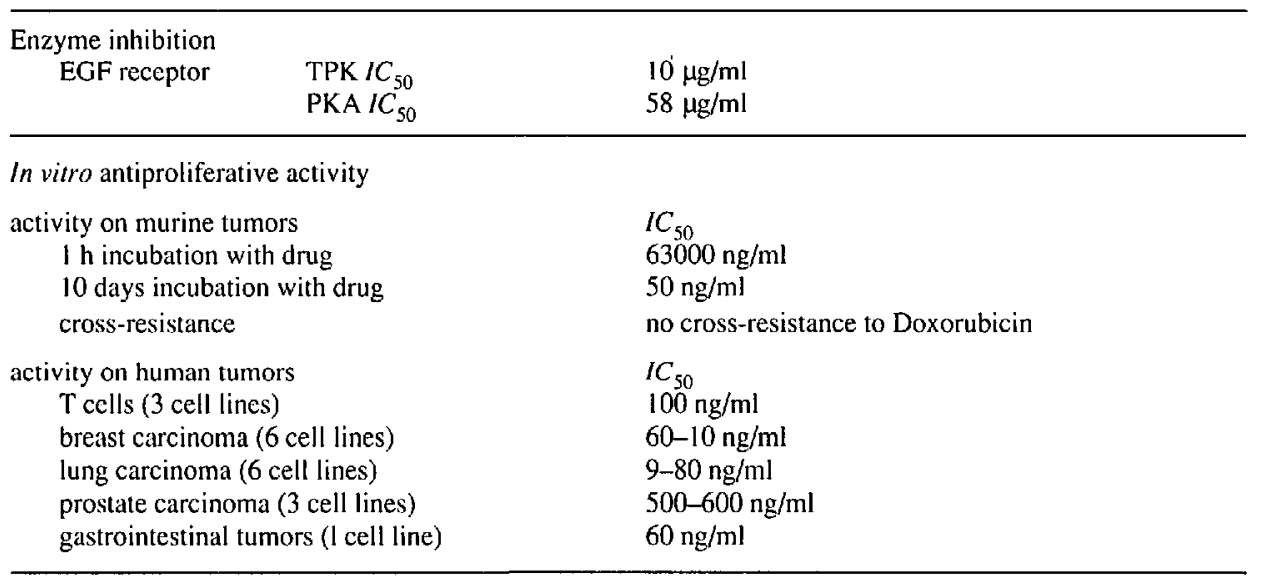

In vivo activity on human tumors

transplanted into kidney of nude mice (bronchial, breast, ovarian,

and colon tumors)

transplanted subcutaneously into nude mice (bronchial, breast, CNS tumors)

One compound is a polysulfated xylan (HoelBay 946), which is currently in phase I/ II clinical studies at the NCI, Bethesda, USA, to evaluate its maximal tolerated dose, the dose limiting toxicity, and its antitumoral activity. HoelBay 946 inhibits very selectively the TPK and less the serine phosphokinase (PKA). Hoe/Bay 946 is not active when applied perorally [43a] (see Table 2).

The other compound is a derivative ( $L 86$ 8275 ) of rohitukin, a natural flavon derivative [43b] isolated out of dysoxylum binectariferum. $L 868275$ inhibits the TPK as well as the serine phosphokinase. Inhibition of both types of enzymes may explain the very high antiproliferative effect of $L 868275$. $L 868275$ is of broad antitumoral activity irrespective, whether it is applied orally or by parenteral routes [43b] (see Table 3).

$L 868275$ is now being evaluated intensively in various tumor pharmacological assays at Behringwerke as well as at the NCI, ficient specificity for tumor associated antigens can be generated. After labeling, e.g. with Technetium $\left(\mathrm{Tc}^{99 m}\right)$, such antibodies are able to localize tumors of more than 0.5$\mathbf{I ~ c m}$ in diameter to such a degree that an immunoscintigraphic detection in the patient is possible. Extensive clinical studies showed $e . g$. that in ca. $80-90 \%$ of patients recurrences or metastases of colon carcinomas can correctly be diagnosed by immunoscintigraphy with the help of a $\mathrm{Tc}^{99 \mathrm{~m}}$ labeled monoclonal antibody specific for CEA $(B W$ $431 / 26$ ). In a number of patients this diagnostic procedure revealed information, which were decisive for therapy and could not be achieved with any other conventional diagnostic procedure (for a review, see [37]). In face of these advantages we are now preparing a drug license application for the antibody $B W 431 / 26$ in Europe.

The clinical in vivo diagnostic investigations made it possible to determine in the patient the distribution of murine antibodies, the localization rate in normal tissues and in the tumor, and the organspecific metabolization.

According to these clinical investigations we know that the localization rate is (at its maximum) $c a .0 .01 \%$ of the applied antibody per gram tumor (for a review, see [37]). Moreover, we know that the antibody specifically localized in the tumor is slower metabolized than the remaining $99.9 \%$ of the administered antibody in blood or in normal tissues (preferently liver and lung), which is metabolized within a period of $c a$. $10-14 \mathrm{~d}$ [45]. The antibodies binding to tumor antigens can be detected in tumor tissues in considerable amounts even after 4 weeks [45].

The rate of specific tumor targeting is. background in normal tissues (a factor of 610 fold) is still at least by a factor of 10 too low to allow successful therapy without damaging of normal tissues [37]. Consequently, in the majority of clinical studies for therapy of solid tumors with immunotoxins, immunocytostatics, or radioimmunoconjugates side effects have been observed but altogether clinically significant tumor therapeutic effects have not been detected [46-53]. In leukemia and lymphoma the situation is more advantageous. In these 'dispersed' tumors cells are directly accessible for i.v. applied specific antibodies. Consequently, the localization rate is much higher than in solid tumors. Thus, the chance of an effective therapy with 'naked' antibodies, with immunocytostatics, immunotoxins or antibody isotope conjugates is higher.

Therapeutic activity of antibody conjugates in leukemia and lymphoma was observed in several clinical studies [54-57]. This therapeutic activity of antibody conjugates, however, competes with numerous other therapeutic treatments, and it remains to be seen, which therapeutic treatment will be more effective.

In contrast to leukemia and lymphoma most solid tumors are resistant to any kind of 


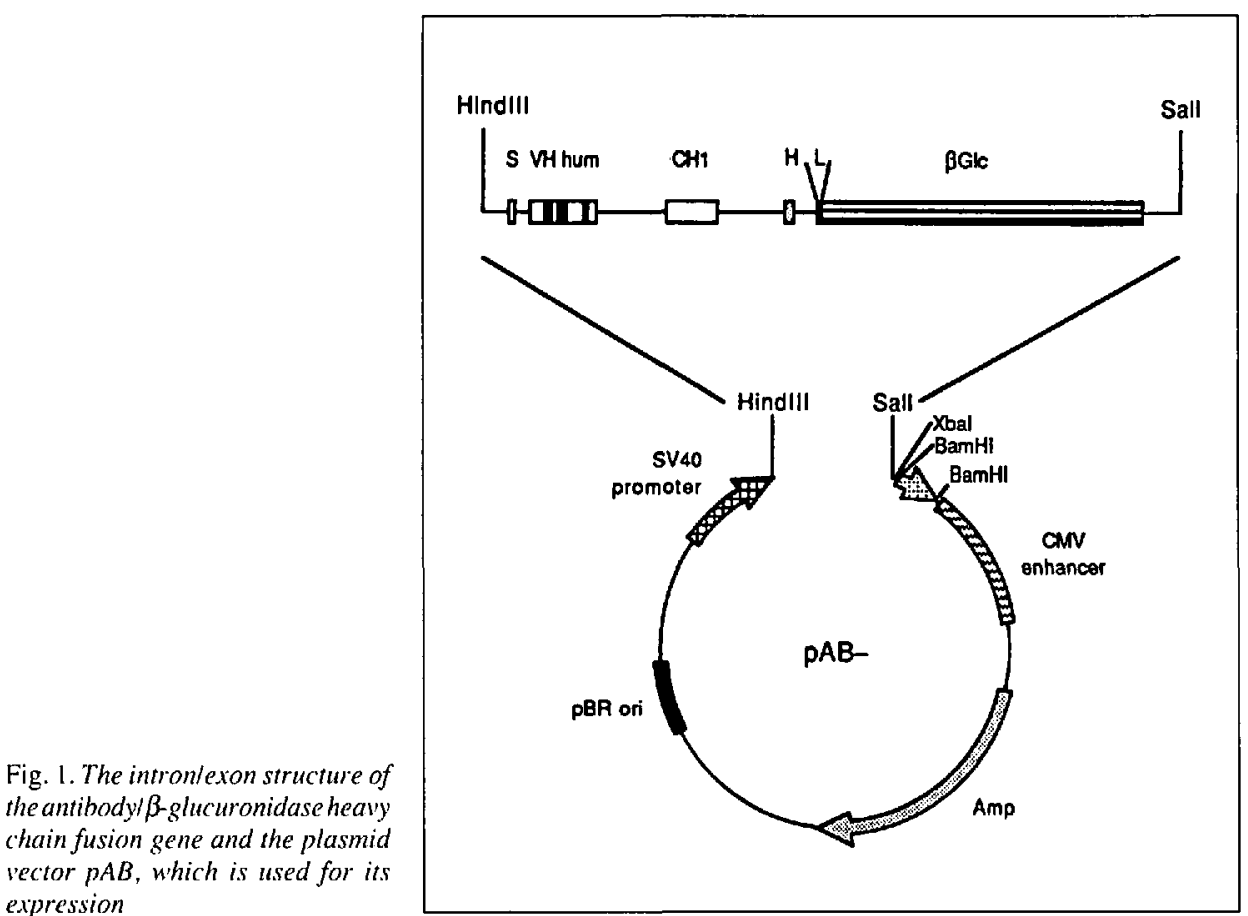

treatment and, therefore, represent the major challenge for tumor therapy in future.

Till now the original idea to treat solid tumors with specific monoclonal antibodies endowed with optimal effector functions (i.e. which are cytolytic via activation of the complement system and/or via activation of cytotoxic cells) has not met with the expected success. It may be speculated that this failure may be caused either by a strong resistance of cells of solid tumors to humoral or cellular lytic mechanisms or by a qualitative or quantitative insufficiency of the lytic mechanisms in tumor patients.

Another simple reason at least in a part of the clinical studies may be that dosages of the monoclonal antibodies have been applied, which are too low to achieve a therapeutic effect.

Therefore, it is likely that future strategies for the therapy of solid tumors with monoclonal antibodies will not be effective without exogenous cytotoxic molecules. Ideally, these cytotoxic molecules should be active only on the tumor site but not on normal tissue. An approach, which may fulfill this requirement, is the biphasic immunospecific enzyme-mediated chemotherapy, in literature named ADEPT (antibody dependent enzyme-mediated prodrug therapy) [58-60].

ADEPT consists of two components. In a first phase an antibody enzyme conjugate (whereby the selected enzyme should not be present extracellularly, e.g. in human blood) is injected. In a second phase a hydrophilic relatively untoxic prodrug of small molecular weight is applied. The latter should be cleaved into a lipo- and cytophilic cytotoxic drug by the enzyme linked to the antibody.

After application to a tumor patient, the antibody enzyme conjugate will localize the tumor according to its antigen specificity. The kinetic of localization is dependent on the diffusion rate and the size of the mole- jugate to generate the cytotoxic drug.

The aspired result should be a local enrichment of the cytostatic drug at the tumor site, sufficient to kill all tumor cells, irrespective whether they have bound the antibody enzyme conjugate or not.

The ADEPT concept is presently being elaborated by different research groups.

First results of clinical pilot studies are already available, which show on one hand that by ADEPT a regression of tumors resistant to conventional therapy is possible. On the other hand the results very clearly disclose the problems. The most evident problem at the moment is the immunogenicity of the antibody enzyme conjugate [67].

Till now murine monoclonal antibodies were used to which xenogeneic enzymes (from bacteria or animals) were conjugated chemically. After application of such antibody enzyme conjugates a humoral immune response arises in the recipient, which inactivates the antibody as well as the enzyme part of the antibody enzyme conjugate. Facing this problem our work had the aim to reduce the immunogenicity of the antibody enzyme conjugate by humanization of the murine antibody and by the selection of a suitable human enzyme.

We selected the murine antibody $B W 43 I I$ 26 [68], which is specific for an epitope on CEA and which already proved to be suitable for the immunoscintigraphy of tumors. We succeeded in the humanization of this antibody that means we transplanted the antigen binding parts of the variable region from the murine antibody into a human antibody framework by using recombinant DNA technologies [69]. The resulting humanized anti CEA antibody $B W h u 431 / 26$ showed the same specificity and avidity as the parenteral murine antibody.

To the Fab fragments of the humanized antibody the human enzyme $\beta$-glucuroni-

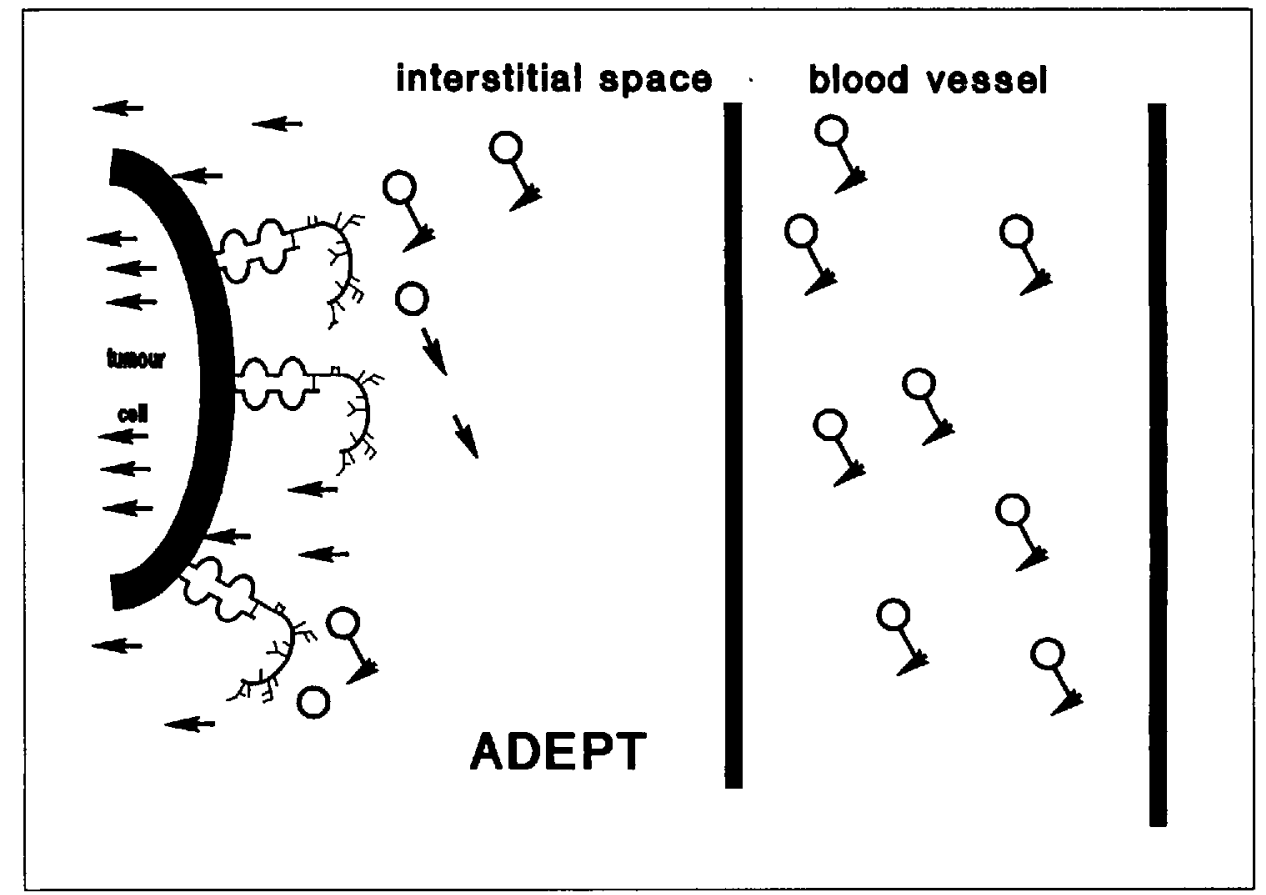

Fig. 2. Principal reaction of antibody directed enzyme-mediated prodrug therapy (ADEPT) 
dase was successfully fused $v i a$ an adequate peptide linker again using recombinant DNA technology [70] (Fig. l). We now have a cell line, which is producing the human antibody enzyme fusion product ' $B W h u 431 / 26$ (Fab)$\beta$-glucuronidase'. Both, the antibody specificity and avidity as well as the enzymatic activity, are fully maintained in this antibody enzyme fusion protein [71].

In addition to the antibody enzyme fusion protein we now need the second component, a suitable prodrug. The synthesis of this prodrug is in process in cooperation with different partners. As a first example we synthesized etoposid 4'- $\beta$-glucuronide [72]. Our hope for the near future is to have both components in sufficient amounts in our hands, so that we can perform the essential tumor pharmacological investigations.

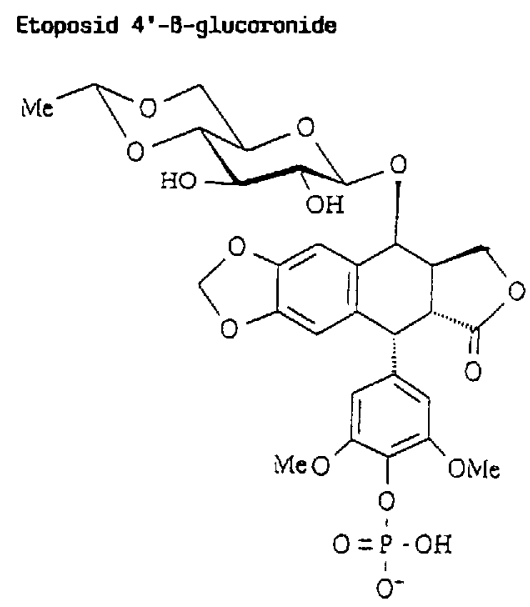

It can be foreseen that the field of application of ADEPT is not restricted to tumor therapy (Fig. 2). Important therapeutic indications may additionally be the elimination of cells of the immune system, of virus infected cells (e.g. in chronic HBV or HIV infection) or even of bacteria or parasites being resistant to conventional chemotherapy or antibiotics. Moreover, the ADEPT system may also be suitable for local fibrinolysis of blood clots [73].

In such additional therapeutic indications different from tumor therapy the antibody specificity and the prodrug/drug component in the ADEPT system has to be exchanged or adapted accordingly.

A further possibility for a biphasic therapy with the use of exogenous cytotoxic molecules is the application of bispecific antibody molecules [74]. Hereby one specificity of the bispecific antibody is binding to the target cell, e.g. tumor cell, the second specificity is catching the exogenous cytotoxic molecule [75-79]. Currently, we are engaged in construction of such bispecific antibody molecules by recombinant DNA technology [80][81]. As cytotoxic molecule we selected a complex formed by a chelating agent and $Y^{90}$, an emitter of $\beta$-radiation. In the complex with the chelating agent $Y^{90}$ is quickly secreted via the kidney and looses its affinity for bones and its toxicity for bone marrow.

After application the bispecific antibody should localize the tumor and should be metabolized in normal tissue and blood as described earlier. After waiting an adequate time the isotope $\mathrm{Y}^{90}$, complexed with the chelating agent, is injected. A part of the complexed $\mathrm{Y}^{90}$ is bound to the tumor via the bispecific antibody and can carry out its radiotoxic effect for the tumor cells. Nonbound isotope complexes are eliminated via the kidney very quickly. Using such a system we hope to get access to a successful biphasic radioimmunotherapy of tumors.

The application of bispecific antibodies in biphasic treatments is also not restricted to tumor therapy. Similar as with ADEPT the specific elimination of cells of the immune system, of virus infected cells or of parasites or bacteria or the targeting of $\mathrm{fi}$ brinolysis [82] may be possible. According to the chosen indication the target cell specificity of the bispecific antibody and the kind of the cytotoxic molecule has to be selected.

As an alternative to therapy, bispecific antibody molecules may be used for the in vitro and in vivo diagnosis of various diseases. A speciality with an enormous potential would be the use of bispecific antibodies to increase the immunogenicity of vaccines [83]. Such bispecific antibodies should link the immunogen with MHC class II antigens.

\section{Summary}

Three research projects for tumor therapy are presented, which are based on the experience gained so far in tumor physiology and therapy. The conception of and research in these projects have been possible by the increasing knowledge in the growth behavior and control of normal as well as tumor cells and in the role of protooncogenes and oncogenes, moreover, in the insight we have achieved in the components of the immune system, and in the interaction with each other and tumor cells, and in the techniques of generating monoclonal antibodies and modifying them by antibody engineering.

A bifunctional cytostatic $(B 880308)$ has been synthesized consisting in an intercalating anthracycline and a sugar moiety with an epoxy site chain. Its preclinical antitumoral activity is superior to conventional anthracyclines. No cross-resistance to any known cytostatic compound could be detected. Special activity could be observed in human ovarian carcinoma, and it remains to be seen, whether this compound will clinically fulfill the expectations, which arose out of the preclinical studies.

Two growth factor inhibitors could be found (Hoe/Bay 946, a polysulfated xylan, and $L 868275$, a flavone derivative originating from rohitukin), which both block the growth factor receptor associated tyrosine phosphokinase to such a degree and specificity that in vitro as well as in vivo a significant antitumoral activity could be observed.
The antitumoral activity is of considerable broadness. We will see, whether this preclinical activity can also be found in the tumor patient.

Two possibilities of a biphasic antibody mediated tumor therapy with exogenous toxic molecules are presented. The first step of these biphasic therapeutic approaches is the application of an untoxic antibody fusion protein. After the antibody fusion protein has localized and is preserved at the tumor site but has already been metabolized in normal tissue and blood, the second step of the treatment is performed, which consists of the application of an exogenous cytotoxic compound.

In case the antibody fusion protein is an antibody enzyme conjugate, the cytotoxic compound is an untoxic prodrug, which is cleaved into a cytotoxic drug at the tumor site by the enzyme linked to the antibody. In case the antibody fusion protein is a bispecific antibody, the cytotoxic compound is e.g. an isotope ( $\beta$-emitter) complexed with a chelating agent. Only those isotope complexes, which bind to the tumor via the bispecific antibody, can be radiotoxic. Isotope complexes, not bound by the antibody, will be excreted very quickly via the kidney.

Both approaches of the biphasic tumor therapy represent a combination of target cell localization of the antibody part (first phase) and (second phase) of an antibody directed cytotoxic activity of a synthetic exogenous compound.

As the limits of the tumor therapeutic activity of antibodies as well as of synthetic cytotoxic compounds are more or less wellknown, the combination of both may lead to a new generation of drugs, which can not only be of importance in the elimination of tumor cells but also of immune cells, virus infected cells, blood clots, bacteriae, or parasites.

The authors thank Mrs. Manuela Rogula for the skilled typing of the manuscript.

[1] A. Gilman, F.S. Philips, Science 1946, 103, 409.

[2] A. Gilmann, Am. J. Surg. 1963, 105, 574.

[3] S. Farber, L.K. Diamond, R.D. Mercer, R.F. Sylvester, Jr., J.A. Wolff, New' Engl. J. Med. $1948,238,787$.

[4] H.H. Sedlacek, D. Hoffmann, G. Schulz, J. Czech, B. Greifenberg, G. Dickneite, H.-P. Kraemer, 'Contributions to Oncology', Karger Verlag, München, 1989, Vol. 34.

[5] J.E. McCormick, R.S. McElhinney, Eur. J. Cancer 1990, 3, 207.

[6] P. Hilgard,Cancer Treatment Rev. 1987, 14, 187.

[7] D. Newell, A. Gescher, St. Harland, D. Ross, Ch. Rutty, Cancer Chemother. Pharmacol. 1987,19, 91.

[8] C. Wasternack, B. Hause, Die Pharmazie 1987, 2,73 .

[9] P.J. O'Dwyer, S.A. King, D.F. Hoth, B. LeylandJones, Cancer Res. 1987, 47, 391 I.

[10] J.H. Beijnen, H. Lingeman, H.A. van Munster, W.J.M. Underberg, J. Pharmac. Biomed. Anal. $1986,4,275$.

[11] R.B. Weiss, G. Sarosy, K.Glagett-Carr, M.Russo, B.Leyland-Jones, Cancer Chemother. Pharmacol. 1986, 18, 185. 
[12] C.J. Allegra, J.C. Drake, J. Joliven, B.A. Chabner, Proc.Natl. Acad. Sci. U.S.A. 1985, 82,4881.

[13] A.R. Beard, M.G.B. Drew, P. Hilgard, B.D Hudson, J. Mánn, S. Neidle, L.F.T. Wong, AntiCancer Drug Design 1987, 2, 247.

[14] J. Haiduc, C. Silvestru, Coord. Chem. Rev. 1990, 99, 253.

[15] J.G.M. Klijn, F.H. de Jong, G.H. Bakker, St.W.J. Lamberts, C.J. Rodenburg, J. Alexieva-Figusch, Cancer Res. 1989, 49, 2851.

[16] H.J. Harmsen, Jr., A.J. Porsius, Eur. J. Cancer Clin. Oncol. 1988, 24, 1099.

[17] A. Howell, D.J.Dodwell, H. Anderson, Bailliere's Clin. Endocr. Metab. 1990, 4, 67.

[18] J.M. Cassady, W.M. Baird, C. Chang, J.Nat.Prod. $1990,53,23$.

[19] W.J. Slichenmyer, D.D. Von Hoff, J. Clin. Pharmacol. 1990, 30, 770.

[20] B. Winograd, M.W. Lobbezoo, H.M. Pinedo, J.H. Beijnen, F.E. Durr, 6th NCI-EORTC symposium on new drugs in cancer therapy, Amsterdam, 1989.

[21] J.M. Brown, E.M.Zeman, K.A. Bidermann, M.J. Lemmon, M. Tracy, 6th NCl-EORTC symposium on new drugs in cancer therapy. Amsterdam, 1989.

[22] R.L. Tuttle, V.S. Lucas, N.J. Clendeninn, J.D. Purvis, 6th NCI-EORTC symposium on new drugs in cancer therapy, Amsterdam, 1989.

[23] C. Sessa, M.Zucchetti, Y.Willems, M. D'Incalci, F. Cavalli, 6th NCI-EORTC symposium on new drugs in cancer therapy, Amsterdam, 1989.

[24] J.P. Armand, G. Recando, A. Gouyette, M. Belerahdek, M. Bonnay, G. Chabot, C. L'Homme, 6th NCI-EORTC symposium on new drugs in cancer therapy, Amsterdam, 1989.

[25] A.M. Casazza, J.E. Schurig, S. Forenza, B.H Long, W.C. Rose, J.J. Catino, H. Kamei, Y. Nishiyama, W.T. Bradner, R. Trail, J. Matson, A Crosswell, T.W. Doyle, 6th NCI-EORTC symposium on new drugs in cancer therapy, Amsterdam, 1989.

[26] G.B. Grindey, L.W. Hertel, V. Heinemann, W Plunkett, P.J. Houghton, J.A. Houghton, 6th NCIEORTC symposium on new drugs in cancer therapy, Amsterdam, 1989.

[27] R.L. Schilsky, M. Ratain, J. Grayhack, K Breedlove, S. Lucas, R. Tuttle, 6th NCI-EORTC symposium on new drugs in cancer therapy, Amsterdam, 1989.

[28] P.J. Hoghton, J.A. Houghton, G.B. Grindey, 6th NCl-EORTC symposium on new drugs in cancer therapy, Amsterdam, 1989.

[29] H.P. Kraemer, H.G. Berscheid, H. Ronneberger, H. Zilg, H.H. Sedlacek, Sth NCI-EORTC symposium on new drugs in cancer therapy, Amsterdam, 1986.

[30] J. Verweij, M.E.L. van der Burg. W.L.J. von Putten, H.P. Kraemer, E. Weidmann, G. Stoter Proceedings 4th European conference on clinical oncology and cancer nursing, Madrid, 1987.

[31] G. Falkson, H.C. Falskon, A.S. Alberts, Eur. J Cancer 1990, 26, 71 .

[32] H.H. Sedlacek, 'Beiträge zur Onkologie', Karger Verlag, München, 1987, p. 25.

[33] D. Newling, Cancer 1990, 6I, 497.

[34] Ch.G. Moertel, T.R. Fleming, J.S. Macdonald,
D.G. Haller, J.A. Laurie, P.J. Goodman, J.S. Ungerleider, W.A. Emerson, D.C. Tormey, J.H. Glick, M.H. Veeder, J.A. Mailliard, New Engl.J. Med. 1990, 352.

[35] J.F. Smyth, Cancer Treatment Rev. 1988, 15, suppl. A 3.

[36] J Atzpodien, H. Kirchner, Klin. Wochenschr. 1990, 68, 1.

[37] H.H. Sedlacek, G. Schulz, A. Steinstraesser, L. Kuhlmann, A. Schwarz, L. Seidel, G. Seemann, H.-P. Kraemer, K. Bosslet, 'Contributions to Oncology. Karger Verlag, München, 1988, p. 32.

[38] U. Stache, H.H. Sedlacek, D. Hoffmann, H.-P. Kraemer, J. Cancer Res. Clin. Oncol. 1990, 116 , suppl. part I, 439.

[39] P. Hermentin, E. Raab, C. Kolar, M. Gerken, D. Hoffmann, H.-P. Kraemer, U. Stache, Eur. Patentanmeldung. Veröffentlichungsnr.: 0345598. Anmeldenr.: 89109689.31989.

[40] D. Hoffmann, M. Gerken, P. Hermentin, H.H. Sedlacek, 82nd Annual Meeting of the AACR for cancer research, Houston, 1991.

[4I] A. Ullrich, J. Schlessinger, Cell 1990, 6I, 203.

[42] J. Czech, H.H. Sedlacek, Cancer Chemother. Pharmacol. 1989, 24, suppl. 2, 72.

[43] a) J. Czech, D. Hoffmann, G. Dickneite, C.E. Myers, H.H. Sedlacek, J. Cancer Res. Clin. Oncol. 1990, II6, suppl,, part 1, 474; b) J. Czech, D. Hoffmann, Ch.E. Myers, I.D. Horak, E.A. Sausville, H.H. Sedlacek, 4 h Int. Congress on Hormones and Cancer, Amsterdam, 1991.

[44] R.G. Naik, B. Lal, R.H. Rupp, H.H. Sedlacek, G. Dickneite, J. Czech, Patentanmeldung Nr.: $89119710.5,1989$.

[45] R.H.J. Begent, 6th Int. Conf. on Monoclonal Antibody Immunoconjugates for Cancer, San Diego, 1991.

[46] T. Takahashi, T. Yamaguchi, K. Kitamura, H. Suzuyama, M. Honda, T. Yokota, H. Kotanagi, M. Takahashi, Y. Hashimoto, Cancer 1988, 6I, 881.

[47] P. von Wussow, L. Spitler, B. Block, H. Deicher, Eur. J. Cancer Clin. Oncol. 1988, 24, suppl. 2, 69.

[48] B.J. Gould, M.J. Borowitz, E.S. Groves, P.W. Carter, D. Anthony, L.M. Weiner, A.E. Frankel, J. Natl. Cancer Inst. 1989, 8I, 775.

[49] L.M. Weiner, J. O'Dwyer, J. Kitson, R.L. Comis, A.E. Frankel, R.J. Bauer, M.S. Konrad, E.S. Groves, Cancer Res. 1989, 49, 4062.

[50] V.S. Byers, R. Rodvien, K. Grant, L.G. Durrant, K.H. Hudson, R.W. Baldwin, P.J. Scannon, Cancer Res. 1989, 49, 6153 .

[51] St.M. Larson, A. Raubitschek, J.C. Reynolds, R.D. Neumann, K.-E. Hellstrom, I. Hellstrom, D. Colcher, J. Schlom, E. Glatstein, J.A. Carrasquillo, Nucl. Med. Biol. 1989, 16, 153.

[52] J.B. Alexander, M.B. McEwan, 6th Int. Conf. on Monoclonal Antibody Immunoconjugates for Cancer, San Diego, 1991.

[53] D.G. Haller, 6th Int. Conf. on Monoclonal Antibody Immunoconiugates for Cancer, San Diego, 1991.

[54] B. Parker, 6th Int. Conf. on Monoclonat Antibody Immunoconiugates for Cancer, San Diego, 1991.

[55] C.R. Divgi, 6th Int. Conf. on Monoclonal Anti- body Immunoconjugates, San Diego, 1991.

[56] D.M. Goldenberg, 6th Int. Conf. on Monoclonal Antibody Immunoconjugates, San Diego, 1991.

[57] W.A. Blattler, 6th Int. Conf. on Monoclonal Antibody Immunoconjugates, San Diego, 1991.

[58] G.W. Philpott, R.J. Bower, Ch.W. Parker, Surgery 1973, 74, 51

[59] G.W. Philpott, R.J. Bower, K.L. Parker, W.T Shearer, Ch.W. Parker, Cancer Res. 1974, 34, 2159

[60] G.W. Philpot, E.H. Grass, Ch.W. Parker, CancerRes. 1979, 39, 2084.

[6I] P.L. Carl, 'Development of target-oriented anticancer drugs.' Raven Press ••, 1983.

[62] K.D. Bagshawe, Br. J. Cancer 1987, 56, 531.

[63] K.D. Bagshawe, Br. J. Cancer 1989, 60, 275

[64] P.D. Senter, G.J. Schreiber, D.L. Hirschberg, S.A. Ashe, K.E. Hellström, 1. Hellström, Cancer Res. 1989, 49, 5789.

[65] D.E. Kerr, P.D. Senter, W.V. Burnett, D.L. Hirschberg, I. Hellström, K.E. Hellström, Cancer Immunol Immunother. 1990, 31, 202.

[66] P.D. Senter, FASEB J. 1990, 4, 188.

[67] K.D. Bagshawe, 6th Int. Conf. on Monoclonal Antibody Immunoconjugates, San Diego, 1991.

[68] K. Bosslet, A. Steinstraesser, A. Schwarz, H.P. Harthus, G. Lueben, L. Kuhlmann, H.H. Sedlacek, Eur. J. Nucl. Med. 1988, 14, 523.

[69] D. Guessow, G. Seemann, Mesh. Enzymol. (accepted for publication, 1991).

[70] G. Seemann, P. Lorenz, J. Czech, H.H. Sedlacek M. Schuermann, K. Bosslet, in preparation.

[71] K. Bosslet, J. Czech, H.H. Sedlacek, G. Seemann, 8th Int. Hammersmith Meeting, Greece, 1991.

[72] C. Kolar, J. Czech, K. Bosslet, G. Seemann, H.H Sedlacek, Patentanmeldung Nr. P 3935016.9 1989.

[73] Ch. Bode, G. R. Matsueda, K. Y. Hui, E. Haber, Science 1985, 229, 765.

[74] O.Nolan, R. O'Kennedy, Biochim. Biophys. Acta 1990, 1040, 1.

[75] U. Sahin, F. Hartmann, P. Senter, Ch. Pohl, A. Engert, V. Diehl, M. Pfreundschuh, Cancer Res. 1990, 50, 6944

[76] J.L. Phelps, D.E. Beidler, R.A. Jue, B.W. Unger M.J. Johnson, J. Immunol. 1990, 145, 1200.

[77] W.Smith, V.A. Gore, D.R. Brandon, D.N. Lynch, S.A. Cranstone, J.R.F. Corvalan, Cancer Immunol. Immunother. 1990, 31, 157.

[78] S. Honda, Y. Ichimor, S. Iwasa, Cytotechnology $1990,4,59$.

[79] J.-M. Le Doussal, A. Gruaz-Guyon, M. Martin, E. Gautherot, M. Delaage, J. Barbet, Cancer Res. $1990,50,3445$

[80] K. Bosslel, P. Hermentin, L. Kuhlmann, A Steinstraesser, G. Seemann, H.H. Sedlacek, Cancer Treatment Rev. 1990, 17, 355.

[81] K. Bosslet, A. Steinstraesser, P. Hermentin, L. Kuhlmann, A. Bruynck, M. Magerstaedt, G. Seemann, A. Schwarz, H.H. Sedlacek, submitted to Br.J. Cancer

[82] M.S. Runge, Ch. Bode, Ch.E. Savard, G.R Matsueda, E. Haber, Bioconjugate Chem. 1990, 1,274 .

[83] D.P. Snider, A. Kaubisch, D.M. Segal, J. Exp. Med. 1990, 17I, 1957. 